\title{
Dwa świadectwa o wyprawie Iwana III na Nowogród w 1471 roku. Przyczynek do kształtowania się ideologii władzy monarszej
}

Nowogród Wielki, wraz z Kijowem, od samego początku istnienia państwa ruskiego odgrywał $\mathrm{w}$ nim najbardziej istotną rolę. W obu tych ośrodkach powstały najwcześniejsze zwody latopisarskie ${ }^{1}$. Nowogród przewyższał wszystkie dzielnice pod względem rozwoju ruchu monastycznego. Był też republiką, co poza Pskowem w zasadniczy sposób odróżniało go od pozostałych części państwa ruskiego. Świadomi swej wartości, manifestujący odrębność i uwypuklający własną rolę Nowogrodzianie wywodzili początki swego miasta od Jafeta i głosili, że jako jedyni spośród wszystkich mieszkańców ziem ruskich przyjęli chrzest nie z Bizancjum, ale od św. Andrzeja, apostoła. Do rangi symboli republiki urosły biały kłobuk i ikona Matki Boskiej Tychwińskiej przeniesione przez Boga z Bizancjum do Nowogrodu².

Rolę czynnika decydującego o wszystkich najbardziej istotnych dla republiki sprawach odgrywał wiec $^{3}$, którego prerogatywy obejmowały również wybór biskupa. Od połowy XII w. jedynie konsekrowanego przez metropolitę. W momencie, gdy od 1165 r. Joan został pierwszym nowogrodzkim arcybiskupem, znaczenie republiki wzrosło jeszcze bardziej. Nowogród, w przeciwieństwie do pozostałych części Rusi, stosunkowo najmniej ucierpiał w wyniku najazdu mongolskiego. Uznawał wprawdzie zwierzchnictwo chana i zobowiązywał się do płacenia ,čornego boru”, ale nie został zmuszony do wyrażenia zgody na obecność na swym terytorium baskaków ${ }^{4}$. Szczególne znaczenie nadilmeńska republika przywiązywała do „stariny”, która regulo-

${ }^{1}$ A.L. Šapiro, Russkaja istoriografija s drevnejšych vremion do 1917 goda, Moskva 1993, s. $68-82$.

${ }^{2}$ J.H. Billington, Ikona i topór. Historia kultury rosyjskiej, tł. J. Hunia, Kraków 2008, s. 75.

${ }^{3}$ H. Birnbaum, Średniowieczny Nowogród. Życie polityczne, społeczne i kulturalne w staroruskiej wspólnocie miejskiej, [w:] Chrześcijaństwo Rusi Kijowskiej, Białorusi, Ukrainy i Rosji (X-XVII wiek), red. J. Kłoczowski, „Rozprawy PAU”, Wydz. histor.-filozof., og. zb. T. 85, Kraków 1997, s. $139 \mathrm{nn}$.

${ }^{4}$ A.N. Sacharov, Cerkov v period feodalnoj rozdroblennosti, [w:] Christianstvo i Rus. Sbornik statej, Moskva 1988, s. 65. 
wała kwestie ustrojowe i organizację państwa. Najbardziej wymownym symbolem pełnej nowogrodzkiej niezależności było określanie republiki mianem „Gospodin Velikij Novgorod".

Nowogród Wielki właściwie przez cały czas swego istnienia musiał dbać o zachowanie tej skrzętnie pielęgnowanej niezależności, co wcale nie było rzeczą łatwą. Podstawą porozumień nowogrodzko-moskiewskich był układ z 1270 r., pozwalający republice zachować „starinę”. . Czasy „niewoli mongolskiej" wprowadziły pewne uzupełnienia do wzajemnych nowogrodzkomoskiewskich stosunków. Chan Uzbek w 1328 r. przekazał Iwanowi Kalicie władzę nad republiką św. Zofii, ale i tym razem z zachowaniem względnej suwerenności (m.in. polityka zagraniczna i nienaruszalność granic) ${ }^{6}$. Nadilmeńska niezależność w szczególny sposób doskwierała książętom moskiewskim, którzy nie tracili nadziei, że prędzej czy później uda im się Nowogród w pełni podporządkować. Swe prawa zwierzchnie do panowania nad nim wywodzili zresztą od książąt włodzimiersko-suzdalskich, a ich początek widzieli w czasach Wsiewołoda „Wielkie Gniazdo”. Jest to fakt zasługujący na specjalne podkreślenie, ponieważ Wsiewołod był pierwszym ruskim księciem, który programowo posługiwał się tytulaturą wielkoksiążęcą ${ }^{7}$. Iwan Kalita zaczął wprawdzie sporadycznie używać tytulatury „,velikij knjaz’ vseja Rusi”, ale co dla tych rozważań ma kolosalne znaczenie - ograniczał ją do kontaktów właśnie z Nowogrodem ${ }^{8}$.

Republika św. Zofii, często w sposób wręcz mistrzowski, od XIV w. lawirowała między niebezpiecznymi sąsiadami, Moskwą i Litwą ${ }^{9}$ Zapraszając na „kormlenie” któregoś z Rurykowiczów lub Giedyminowiczów, szukała tym samym przeciwwagi dla roszczeń zbyt w danym okresie aktywnie wobec niej ustosunkowanego państwa. „Kormlenia” były manifestacją intencji, mogły gwarantować wsparcie w razie trudności, a jednocześnie w zasadzie w niczym nie ograniczały niezależności republiki. Zapraszani książęta otrzymywali bowiem wprawdzie nieraz bogate ,prigorody”, ale ich prerogatywy, solidnie okrojone, w żaden sposób nie wkraczały w wewnętrzne sprawy gospodarzy ${ }^{10}$.

${ }^{5}$ I.B. Grekov, Vostočnaja Evropa i upadok Zolotoj Ordy, Moskva 1975, s. 33; K. Bojko, Stosunki dyplomatyczne Moskwy z Europa Zachodniq w czasach Iwana III, Kraków 2010, s. 62.

${ }^{6}$ V.N. Bernadskij, Velikij Novgorod i Novgorodskaja Zemla $w X V$ v., Moskva-Leningrad 1961, s. 22-24, 272.

${ }^{7}$ A.A. Zimin, Rossija na rubeže XV-XVI stoletij. Očerki socjalno-političeskoj istorii, Moskva 1982, s. 148; H. Paszkiewicz, Wzrost potęgi Moskwy, Kraków 2000, s. 98.

${ }^{8}$ W. Peltz, Suwerenność państwa w praktyce i doktrynie politycznej Rusi Moskiewskiej (XIV-XVI w.), Zielona Góra 1994, s. 17. Patrz również A. Poppe, O tytule wielkoksiążęcym na Rusi, „Przegląd Historyczny”, 75, 1984, z. 3, s. 432-436.

9 Patrz np. H. Neubauer, Groß-Novgorod zwischen Litauen und Moskau, „Litauische-Kulturinstitut. Jahrestagung" 1989/1990, Lampertheim 1991.

${ }^{10}$ Jak to trafnie ujmował W. Peltz (Suwerenność państwa, s. 101): „Sfera decyzyjna leżała poza ich kompetencjami”. 
W dodatku „kormlenia” trwały zazwyczaj krótko. Gdy sytuacja zewnętrzna się normalizowała, rezygnowano z usług wcześniej zaproszonego księcia.

W historiografii spotyka się opinie, że Nowogród w XIV w. znajdował się w orbicie wpływów litewskich ${ }^{11}$. Można się z tym zgodzić, traktując jako stwierdzenie faktu, ale jednocześnie spierać się w odniesieniu do ukazania intencji. Wydaje się bowiem, że ani nie było wówczas ze strony litewskiej skonkretyzowanej polityki wobec Nowogrodu, ani nie była ona prowadzona konsekwentnie. To ostatnie szczególnie może da się dostrzec w czasach wielkoksiążęcych rządów Giedymina ${ }^{12}$. Z kolei książęta moskiewscy, zresztą zdecydowanie inaczej patrzący na Nowogród, mimo że podkreślali dawne związki Moskwy z republiką nadilmeńską, nazywając ją swą „otčiną” na tej samej zasadzie, jak były nią Moskwa i Włodzimierz, dość długo starali się zachowywać pozory, że nie myślą o pełnym podporządkowaniu Nowogrodu ${ }^{13}$. Do połowy XV w. prowadzona przez republikę św. Zofii polityka przynosiła efekty, ponieważ wszelkie układy zawierane przez nią z Litwą i Moskwą opierały się na „starinie” i nie naruszały jej wolności i swobód ${ }^{14}$.

W tym samym czasie Nowogród ${ }^{15}$ jeszcze $\mathrm{z}$ innego punktu widzenia odgrywał ważną rolę w historii Moskwy. Stał się azylem dla pokonanych książąt, eliminowanych chwilowo lub ostatecznie z walki o moskiewski stolec wielkoksiążęcy. W 1434 r. przybył do niego, szukając schronienia, Wasyl II ${ }^{16}$, w 1441 r. jego główny oponent Dymitr Szemiaka ${ }^{17}$, który, po definitywnej klęsce, ponownie znalazł się w Nowogrodzie w 1447 r., gdzie po 6 latach zmar1 $^{18}$. Wnuk Witolda nie zamierzał jednak okazywać wdzięczności za okazane wcześniej wsparcie, zwłaszcza że najpewniej źle odebrał obecność Szemiaki nad Ilmeniem i nie mógł nie dostrzegać wysiłków czynionych przez władykę Epifaniusza II, który wszelkimi sposobami starał się potwierdzać

${ }^{11} \mathrm{~Np}$. H. Paszkiewicz, Jagiellonowie a Moskwa, T. 1: Litwa a Moskwa w XIII i XIV wieku, Warszawa 1933, s. 344-347; J.L.J. Fennell, The Emergence of Moscow 1304-1359, London 1968, s. 138-139, 154-155; V.L. Janin, Novgorod i Litva. Pograničnyje situacii XIII-XIV vekov, Moskva 1998, s. 5-23.

${ }^{12}$ Patrz np. J. Nikodem, Narymunt Giedyminowic i jego uposażenie, [w:] Scriptura custos memoriae. Prace historyczne, red. D. Zydorek, Poznań 2001, s. 609-622.

${ }^{13}$ W. Peltz, Suwerenność państwa, s. 79.

${ }^{14}$ V.N. Bernadskij, Velikij Novgorod, s. 245-246. Dodajmy, że z powodzeniem odnieść to można również do aktywności przejawianej do późnych lat 20. przez Witolda, który zresztą, jak się zdaje, też raczej - trochę z konieczności - zadowalał się swym ,prestiżowym” zwierzchnictwem nad republiką.

${ }^{15} \mathrm{~W}$ XV w. zamieszkiwało go ok. 27 tys. mieszkańców, a cała republika liczyła ok. 400 tys. ludności; patrz M. Małowist, Wschód i Zachód Europy w XIII-XV wieku. Konfrontacja struktur spoleczno-gospodarczych, Warszawa 1973, s. 127.

${ }^{16}$ Novgorodskie letopisi, Sankt Petersburg 1879, s. 52.

${ }^{17}$ Polnoe sobranie russkich letopisej (dalej: PSRL), t. 12, Sankt Petersburg 1901, s. 42; PSRL, t. 8, Sankt Petersburg 1859, s. 111.

${ }^{18}$ Novgorodskie letopisi, s. 53; PSRL, t. 5, Sankt Petersburg 1851, s. 271. 
niezależność Nowogrodu ${ }^{19}$. W efekcie wojska moskiewskie w 1456 r. uderzyły na Nowogród, odniosły zwycięstwo w polu, anektowały Wołogdę, Wołokamsk i Bieżacki Wierch. Pokonani zostali zmuszeni do zapłaty 10 tys. rubli nowogrodzkich, zgodzili się na pozbawienie wiecu uprawnień najwyższej instancji sądowej i uznali w Wasylu księcia nowogrodzkiego ${ }^{20}$. Miało to określone konsekwencje, które niemal natychmiast odnotowano w Pskowie, gdzie o przyjeździe wielkiego księcia do Nowogrodu w 1460 r. napisano: ,prijecha vo svoju otčinu v Novgorod Velikij" ${ }^{21}$. Psków zresztą w tym czasie tracił niezależność, ponieważ Wasyl II zaczął go sobie podporządkowywać od $1461 \mathrm{r}$., a po śmierci swego teścia, księcia Borysa, zaczął również kontrolować Twer, któremu w 1465 r. narzucił zwierzchnictwo zaaprobowane przez Michała Borysowicza ${ }^{22}$.

Pierwszym aktem generalnej rozprawy z Nowogrodem była wyprawa podjęta przez Iwana III, następcę Wasyla, w $1471 \mathrm{r}^{23}$ Wyprawa doskonale przygotowana nie tylko pod względem wojskowym i dyplomatycznym, ale również propagandowym. Moskwa bowiem od samego początku usiłowała usprawiedliwić tę wojnę za pomocą zgrabnie dobranej argumentacji politycznej i religijnej ${ }^{24}$, a źródła proweniencji moskiewskiej opisywały panowanie Iwana III i jego poprzedników wyłącznie w jasnych barwach ${ }^{25}$.

Interesujący nas przekaz, „Moskovskaja povest' o pochode Ivana III Vasil'eviča na Novgorod"26, mówiący o wyprawie z 1471 r. powstał niemal natychmiast po jej zakończeniu (1472 r. $)^{27}$. Spisany z moskiewskiej perspektywy daje doskonałe świadectwo wykorzystywania słowa pisanego jako środka służącego dla uwypuklenia ideowych i propagandowych celów państwa mo-

${ }^{19}$ J. Nikodem, „,Podróż na diable”, „Studia Periegetica”, 2, 2008, s. 73-84, tam dalsza literatura.

${ }^{20}$ Gramoty Velikogo Novgoroda i Pskowa, wyd. S.N. Valk, Leningrad 1949, nr 22-23; Novgorodskie letopisi, s. 53. Patrz V.N. Bernadskij, Velikij Novgorod, s. 257-259; W. Peltz, Suwerenność państwa, s. 105. Zdaniem L. Gumilowa (Od Rusi do Rosji, tł. E. Rojewska-Olejarczuk, Warszawa 2004, s. 173-174), Wasyl II miał zamiar rozpocząć następną wyprawę na Nowogród, ale powstrzymał go metropolita Jonasz.

${ }^{21}$ Pskovskie letopisi, t. 1, wyd. A.N. Nasonov, Moskva-Leningrad 1941, s. 57, 59.

${ }^{22}$ E. Klug, Kniažestvo Tverskoje (1247-1485), Tver 1994, s. 356 nn.; A.A. Zimin, Rossija na rubeže, s. 62.

${ }^{23}$ Tryumfy tego panowania, tryumfy trudne do przecenienia, zapewne nie wynikały z przypadków, jak sądził F. Koneczny w swych dziejach Rosji. Na tendencyjność jego ocen słusznie zwraca uwagę K. Bojko, Stosunki dyplomatyczne, s. 11. Upadek niezależności Nowogrodu omawia Ju.G. Aleksejev, ,, K Moskve chotim”. Zakat bojarskoj riespubliki v Novgorode, Leningrad 1991.

${ }^{24}$ L.V. Čerepnin, Russkaja istoriografija do konca XIX veka, Moskva 1957, s. 85-87; Ju.G. Aleksejev, Pod znamenami Moskvy. Bor'ba za jedinstvo Rusi, Moskva 1995, s. 190, s. 144 nn.

${ }^{25}$ N.A. Kazakova, Russko-livonskie i russko-ganzejskie otnošenia. Konec XIV-načalo XVI v., Leningrad 1975, s. 141 (z instruktażowym wręcz przykładem odnoszącym się do Dorpatu).

${ }^{26}$ Pamjatniki literatury drevnej Rusi. Vtoraja polovina XV veka, red. L.A. Dmitriev, D.S. Lichačev, Moskva 1982.

${ }^{27}$ Ja.S. Lur'je, Kommentarii, [w:] Pamjatniki literatury, s. 627. 
skiewskiego. Podstawowym celem autora „Moskovskoj povesti” było - z jednej strony ukazanie niepodważalnych praw zwierzchnich Iwana III do Nowogrodu, realizowanych w pełnej zgodzie z prawem i tradycją, i z drugiej zaś - przedstawienie nowogrodzkich przeciwników zwierzchnictwa Moskwy w jak najgorszym świetle. Dobrze poinformowany, obdarzony talentem perswazyjnym, orientujący się nie tylko w meandrach polityki wielkoksiążęcej, ale również świadomy oczekiwań związanych z jego tekstem, autor pozostawił świadectwo interesujące i pełne posiadanych z pierwszej ręki szczegółów W odniesieniu do militarnego aspektu rozgrywających się wydarzeńn ${ }^{28}$. W pozostałej warstwie przekazu dostrzegamy faktografię stojącą na usługach myśli przewodniej utworu, a zatem nierzadko przedstawianą w nie zawsze pełnej zgodzie z rzeczywistością, i interpretację do owej faktografii dodaną, która w swej jednoznaczności nie pozostawia złudzeń, że starano się spisać świadectwo przynajmniej w jakiejś mierze zobiektywizowane.

Cechą charakterystyczną utworu jest także jej chronologiczna narracja, dzięki której autor mógł nie tylko uzyskać ułatwiającą czytanie przejrzystość, ale i sposobność do dobitnego, powtarzanego przy każdej okazji, ukazania racji przyświecających obu stronom konfliktu. Tekst nie jest wolny ani od emocji, ani od udziału czynnika nadprzyrodzonego, co czyniło go zapewne w sposób szczególny bardzo przekonującym w oczach odbiorców, do których miał zostać skierowany. Tekst dotyczył bezpośrednio politycznych i ideowych interesów wielkiego księcia moskiewskiego, dlatego nie mógł się charakteryzować powściągliwością, dwuznacznością czy chęcią pozostawienia czytelnikowi rozsądzenia sprawy albo jej przemyślenia, jak można to na przykład dostrzec w sławnym, nieco późniejszym dziele Fiodora Kuricyna poświęconym Władowi Palownikowi ${ }^{29}$.

Głównym bohaterem „Moskovskoj povesti o pochode” nie są historia, Nowogród ani nawet Moskwa z tryumfem jej oręża. Jedynym prawdziwym bohaterem, kreślonym wprawnym piórem, jest wielki książę moskiewski Iwan III. Autor ukazuje swego władcę nie tylko w glorii zwycięzcy. Przede wszystkim czyni zeń, jak sądzę, monarchę idealnego. Opowieść rozpoczyna się neutralnie. Oto Nowogrodzianie przystąpili do wyboru nowego władyki (,,po starine, kakov bjaša obyčaj u nich"), którym został Feofil ${ }^{30}$. Po jego zatwierdzenie wysłano do Moskwy, do Iwana III, posła, który „biti čelom i opasa prosili”, zwró-

${ }^{28}$ Aczkolwiek i one, o czym się niebawem przekonany, otrzymały odpowiednią otoczkę ideologiczną, ponieważ także miały udowadniać słuszność podjętych przez wielkiego księcia działań.

${ }^{29}$ Skazanie o Drakule voevode, [w:] Pamjatniki literatury, s. 554-564. Patrz J. Nikodem, ,, Skazanie o Drakule voevode" - późnośredniowieczna refleksja o władzy monarszej, [w:] Stereotypy bałkańskie. Księga jubileuszowa Profesor Ilony Czamańskiej, red. J. Paszkiewicz, Z. Pentek, Poznań 2011, s. 98-109.

${ }^{30}$ Jak ważna była to postać w Nowogrodzie, świadczy fakt, że arcybiskup odgrywał rolę głowy państwa, przewodnicząc obradom Rady Panów, patrz N.M. Nikol'skij, Istorija russkoj cerkvi, Moskva 1983, s. 62-63; H. Birnbaum, Średniowieczny Nowogród, s. 128. 
cił się o akceptację wyboru, ,jako že i preže sego było prid prednich velikich knjazeich" "31. Wielki książę - tu otrzymujemy rys sprawiedliwego, ale i dbającego o przestrzeganie prawa, ,gosudara” - nie odmówił prośbie, podkreślając, że Nowogród jest jego „otčiną”, dał wyraz zadowoleniu, że Nowogrodzianie nie zaniedbali swych obowiązków, skoro przysłali do niego „biti čelom”, i zaprosił nowego arcybiskupa do Moskwy, by metropolita mógł go konsekrować „,po pranemu obyčaju, kak bylo pri otci moem, velikom knjaze Vasil'e, i pri dede, i pri pradede moem, i preže byvšich vsech velikych knjazech, ich že pod esmy, volodimerskich, i Novogoroda Velikogo, i vseja Rusi”32. Do rysu osobistego Iwana dodano najważniejszy z punktu widzenia moskiewskiej „racji stanu” passus odwołujący się nie tylko do „wiecznych” praw Moskwy do Nowogrodu, ale - co szczególnie ważne, i tak miało zapaść w pamięci - również do „całej Rusi”33. Rys księcia jednoczyciela, odwołującego się do niekwestionowanych praw, doskonale wyjaśniał dalsze partie tekstu.

W następnych fragmentach odbiorca otrzymywał kolejną odsłonę - to „gosudar'" rozczarowany, wprawdzie ani na jotę nie rezygnujący ze swych uprawnień, ale gotowy łaskawie przebaczyć, zwłaszcza że darzy swych poddanych prawdziwym uczuciem. Gdy Iwan III dowiedział się, że Nowogrodzianie pogrążyli się w strasznych błędach, że odmawiają mu posłuszeństwa, a w dodatku zwrócili się o pomoc do Kazimierza Jagiellończyka, postanowił wysłać do Nowogrodu swych posłów. Ci mieli przekazać następujące słowa:

„»Otčina moja estja, ljudi novogorodstii, iznačala: od ded, ot praded našich, ot velikago knjazja Vladimira, krestivšago zemlju Ruskuju, ot pravnuka Rjurikova, pervago velikogo knjazja $v$ zemli vašej. I ot togo Rjurika da iže i do sego dni znali este edin rod tech velikich knjazej, preže kievskich, do velikogo knjazja Dmitreja Jur'eviča Vsevoloda volodimer'skago, a ot togo velikogo knjazja do iže do mene rod ich, my vladaem vami, i žaluem vas, i boronim otovsele, a i kazniti volny že esmy, koli na nas ne po starine smotrite počnete «"34.

${ }^{31}$ Moskovskaja povest', s. 376.

32 Ibidem. Iwan III konsekwentnie podkreślał, że Nowogród jest jego dziedzictwem, patrz np. Duchovnyje $i$ dogovornyje gramoty velikich $i$ udelnych knjazej XIV-XVI vv., wyd. L.V. Čerepnin, Moskva-Leningrad 1950, nr 9. Z czasem pojęcie ,otčiny” nabierało coraz większego znaczenia. Stały się nią (1504 r.) Kijów, Smoleńsk i inne grody, które czasowo posiadała Litwa, patrz Sbornik Imperatorskogo Russkogo Istoričeskogo Obščestva, t. 35 Pamjatniki diplomatičeskich snošenij Moskovskogo gosudarstva s Polsko-Litovskim, Sankt Peterburg 1882, nr 78.

33 Moskwa miała zresztą konkurencję. Podobną argumentacją posługiwało się powstałe w Twerze w latach 1446-1453 Slovo inoka Fomy sławiące księcia twerskiego jako gospodara, samowładcę i spadkobiercę tytułu cesarskiego, Twer zaś jako nową stolicę wiary prawosławnej, patrz W. Philips, Ein Anonymus der Tverer Publizistik im 15. Jahrhundert, [w:] Festschrift für Dmytro Čyževskyj zum 60. Geburstag, Berlin 1954, s. 230 nn.

34 Moskovskaja povest', s. 380. Patrz także Sobranije gosudarstvennych gramot i dogovorov chraniaščichsja v Gosudarstviennoj kolegii inostrannych del, t. 2, Moskva 1819, nr 18; Ju.G. Aleksejev, Gosudar'vseja Rusi, Novosibirsk 1991, s. 65 nn. 
Powyższy fragment przynosi nie tylko pogłębiony wywód genealogiczny Iwana III służący podkreśleniu jego dynastycznych, niepodważalnych praw do Nowogrodu, lekceważąc jakąkolwiek odrębność nadilmeńskiej republiki, do której ta dotychczas przywiązywała kolosalną wagę, bo udowadniała jej tożsamość, ale również podkreślający, na czym w istocie polega egzekwowanie praw wynikających z ,otčiny”. Wielki książę rad jest przypomnieć, że opiekuje się Nowogrodzianami, nagradza ich i broni, ale władny jest również ich poskromić. Odwołanie się do wielkoksiążęcej „stariny” miało w tekście dzieła szczególne znaczenie, ponieważ całkowicie abstrahowało (przez pominięcie jej milczeniem) od „stariny”, którą rządziła się republika św. Zofii, co dotychczas książęta moskiewscy przyjmowali do wiadomości i oficjalnie nie kwestionowali.

Poselstwo, zdaniem autora „Moskovskoj povesti”, nie miało się wyłącznie ograniczyć do powtórzenia przywołanych słów. Miało przekazać Nowogrodzianom wielkoksiążęcą dezaprobatę z powodu związków z królem polskim. Do tej pory nie byli bowiem nigdy podporządkowani ani żadnemu królowi, ani żadnemu wielkiemu księciu litewskiemu, co oznaczało, że nadal tak być powinno. Iwan III rozkazał również powtórzyć: ,a nyneča ot christijan'stva otstupaete k latinstvu črez krestnoe celovane". Ten wątek bardziej szczegółowo poruszę niżej, w tym miejscu koniecznie trzeba jednak wspomnieć o kolejnej odsłonie obrazu idealnego władcy. Wielki książę moskiewski okazuje się, bo inaczej przecież być nie mogło, gorliwym i najlepszym obrońcą prawdziwej wiary. I cecha kolejna. Surowy, wymagający, ale łaskawy, a więc taki, jakim władca być powinien, Iwan przekazuje buntującym się poddanym, że nie czyni im żadnego gwałtu, że nie żąda od nich większych obciążeń, od tych, które obowiązywały za czasów jego przodków, ale w dodatku chce ich nagradzać, darzyć względami i być im nadal życzliwym ${ }^{35}$.

Jakim jeszcze władcą okazywał się Iwan III w przywoływanej relacji? Wolnym od nienawiści, nieuzasadnionej złości i popędliwości. Gdy dowiedział się, że część, ale większa część Nowogrodzian uparcie trwała w buncie, odrzucając jego propozycję załagodzenia konfliktu i oddając się w opiekę polskiego króla, popadł nie w złość, ale w smutek. Żalił się, że Nowogrodzianie, gdy byli poganami, od czasów Ruryka do Włodzimierza, nie porzucali swych władców, by podporządkować się innym, a od Włodzimierza do dziś znają jego ród, podporządkowali mu się we wszystkim, a teraz chcą nie tylko zniszczyć swe dobre imię, ale w dodatku odstąpić od prawosławia. ,»No čto stvoriti - mówił wielki książę - ne vem, no točiju položju upovanie na edinom gospode boze i mnogomilostiv o sem «". Słuchali tego metropolita, matka i bojarzy, którym Iwan powiedział również, że w zaistniałej sytuacji zamierza wyprawić się przeciw Nowogrodowi. Radzono mu, by złożył na-

\footnotetext{
${ }^{35}$ Moskovskaja povest', s. 380.
} 
dzieję w Bogu i spełnił zamiar, ponieważ Nowogrodzianie zasłużyli na karę „za ich niespravlenie i otstuplen'e"36.

Umocniony w swym postanowieniu wielki książę wezwał do siebie wszystkich braci, biskupów, książąt i bojarów, by ich powiadomić o podjętej decyzji. Otrzymał błogosławieństwo od metropolity „i ot vsech svjatitel’ zemli svoeja, i ot vsego svjaščennago sobora”, i rozpoczął przygotowania do wyprawy $^{37}$. Fragmenty, które w tej chwili przywołuję, ukazywały monarchę działającego nie tylko w pełnej zgodzie z Cerkwią, nie tylko mającego jej całkowite poparcie, ale też władcę głęboko religijnego. A więc i w tym wymiarze nie odbiegającego od ideału.

Po zadbaniu o fachowe z punktu widzenia militarnego i politycznego przygotowania do wojny (wspomnę o tym niżej) Iwan III - co nie powinno budzić zdziwienia - oddał się modlitwom. Modlitwom w wielu cerkwiach. Ten stosunkowo obszerny fragment jest jednocześnie najbardziej podniosłą częścią utworu. „V sobornuju že cerkov' prečistyja vladyčice našea Bogorodica prisnodevy Marija knjaz' veliki, všed k čudotvornej ikoni prečistyja Bogorodica Vladimer'skija”, modlił się i łez „,dovolnii izlija”. Następnie udał się do grobu „svjatych otca našego Petra metropolita čjudotvorca”, gdzie również prosił o pomoc i przelewał łzy (to samo czyniąc przy grobach Teognasta, Cypriana, Focjusza i Jony). W monastyrze Archanioła Michała modlił się i łzy przelewał przy grobie metropolity Aleksieja, ,ruskago čjudotvorca”, przybywszy zaś „,v cerkov archistratiga Michaila” modlił się przy grobach przodków (począwszy od Iwana Daniłowicza, na grobie ojca kończąc): „,Ašče duchom daleče este otsjudu, no molitvoju pomozite mi na ostupajuščich pravoslav'ja deržavy vašeja«". Modlił się, jak dodaje autor „Moskovskoj povesti”, we wszystkich cerkwiach i monastyrach. W końcu udał się do metropolity Filipa, prosząc o błogosławieństwo i odpuszczenie grzechów. Ten zaś błogosławił go krzyżem, błogosławił też wojska wielkoksiążęce ,,jako že Samoil Davyda na Gol'jada" 38 .

Ideowe przesłanie tego i wcześniejszych fragmentów nie mogło pozostawiać najmniejszych wątpliwości. I autor dołożył wszelkich starań, by tak się stało. Władca moskiewski, wzór pobożności, z wielką niechęcią podjął decyzję o rozpoczęciu wyprawy wojennej. Przygotował się do niej, jak przystało na reprezentanta Boga na ziemi. Nie zaniedbując żadnego szczegółu, który od niego mógł zależeć, resztę złożył w ręce Stwórcy, patronów Rusi i przodków. To ostatnie miało niemałe znaczenie, bo z jednej strony podkreślało wcześniej wyrażone prawa Moskwy do Nowogrodu, z drugiej czyniło z Iwana najgodniejszego spadkobiercę tradycji dynastycznej. Największe znaczenie miały jednak słowa odnoszące się do obrony wiary. One czyniły z wielkiego księcia

\footnotetext{
${ }^{36}$ Ibidem, s. 382.

${ }^{37}$ Ibidem.

${ }^{38}$ Ibidem, s. 384, 386.
} 
ideał nienaruszalny. Zwłaszcza że potraktowano je niemal jak wezwanie do krucjaty, w dodatku krucjaty słabszego przeciw silniejszemu. Stąd to nieoczekiwane, ale jakże działające na wyobraźnię porównanie Iwana III do Dawida wybierającego się na bój z Goliatem. Polityczna rzeczywistość, która świadczyła o tym, że do roli Dawida mógł pretendować wyłącznie Nowogród, nie miała znaczenia, ponieważ nie o tak pojętą rzeczywistość w utworze chodziło. Osiągano w ten sposób jeszcze jeden cel: wprawdzie prawa Iwana III do Nowogrodu zostały wyraźnie zaakcentowane i nie mogły budzić wątpliwości, ale przekaz odwracał uwagę od polityki. Wielki książę nie szedł na republikę św. Zofii, by ją sobie podporządkować, by rozszerzyć panowanie Moskwy. Szedł, by bronić prawdziwej wiary.

Ten wątek uwypuklono ponownie, gdy autor utworu wspomniał o wymarszu Iwana z Moskwy, który szedł na wroga ,jako že preže praded ego blagovernyj veliki knjaz' Dmitrej Ivanovič na bezbožnago Mamaja i na bogomerzae toe voin'stvo tatar'skoe, tako že i sej blagovernyj veliki knjaz' Ioan na sich otstupnik". Ci bowiem wprawdzie nazywali siebie chrześcijanami, ale „dela ich bjachy goree nevernych”. Autor nie omieszkał wytłumaczyć, dlaczego. Po ponad 500 latach władzy ruskich książąt prawosławnych zwrócili się do króla polskiego i chcieli otrzymać arcybiskupa od katolików. Czynili tak, chociaż Iwan III i metropolita Filip ich od tego odwodzili, „, to - podsumowywał autor - ne goree li si inovernych?" Poganie nie znali Boga, ale Nowogrodzianie znali, trwali w prawdziwej wierze, ale w końcu chcieli ją opuścić dla katolicyzmu. „I tako poide na nich knjaz' velikij ne jako na christian, no jako na inojazyčnik i na otstupnik pravoslav'ja"39. Jeśli wielki książę moskiewski podejmował wyprawę na odstępców i na pogan, mógł czynić wszystko ${ }^{40}$.

I czynił. Podczas zwycięskiego pochodu potrafił jednych odpowiedzialnych „za izmenu i za otstuplenie” karać śmiercią, innych więzić ${ }^{41}$ - to władca surowy, ale sprawiedliwy - gdy jednak wyprawa kończyła się pełnym sukce-

${ }^{39}$ Ibidem, s. 386.

${ }^{40}$ Katolicy potraktowani gorzej od pogan, to wątek wcale nierzadki w moskiewskim piśmiennictwie. W niczym nie przeszkadzały wcześniejsze kontakty Iwana III z Zachodem i papiestwem. Zaczęły się zresztą jeszcze za czasów Wasyla II, patrz N.A. Kazakova, Zapadnaja Evropa v russkoj pismennosti $X V-X V$ vekov. Iz istorii meždunarodnych kulturnych svjazej Rossii, Leningrad 1980, s. 48-49, 65-67; Ju.G. Aleksejev, Pod znamenami Moskvy, s. 190. W czasach Iwana III szczególne znaczenie miała misja Giana Battisty della Volpe i jej konsekwencje, zwłaszcza ślub wielkiego księcia z Zoe Paleolog, patrz A.L. Choroškevič, Russkoe gosudarstvo v sisteme meždunarodnych otnošenij konca XV-načala XVI v., Moskva 1980, s. 178-179; J.G. Aleksejev, Pod znamenami, s. 179-180; K.V. Bazilevič, Vnešnaja politika russkogo centralizovannogo gosudarstva. Vtoraja polovina XV v., Moskva 1952, s. 75-77; E. Winter, Russland und das Papsttum, Bd. 1 von der Christianisierung bis zu den Anfängen der Aufklärung, Berlin 1960, s. 176-178; W. Peltz, Suwerenność państwa, s. 179-180; K. Bojko, Stosunki dyplomatyczne, s. 46-50; K. Chojnicka, Narodziny rosyjskiej doktryny państwowej. Zoe Paleolog - między Bizancjum, Rzymem a Moskwa, Kraków 2008, s. 67 nn.; A. Andrusiewicz, Cywilizacja rosyjska, t. 1, Warszawa 2004, s. 211-212.

${ }^{41}$ Moskovskaja povest', s. 394. 
sem, przyjął „bijących mu czołem” przedstawicieli strony pokonanej i wybaczył im, „utoli gnev svoj”, nie z powodu ich ukorzenia, ale kierując się miłosierdziem, które chciał okazać grzesznikom - to władca przebaczający, a więc podporządkowujący się nakazom Bożym ${ }^{42}$.

Po odniesionym tryumfie mógł Iwan, książę moskiewski i nowogrodzki, wracać do Moskwy jako „vseja Rusi samoderžec”43.

Negatywnymi bohaterami „Moskovskoj povesti” są mieszkańcy Nowogrodu. Nie wszyscy. Tych, którzy okazali zadowolenie po powrocie nowogrodzkiego poselstwa z Moskwy (a zatem na początku przekazu), poselstwa negocjującego w sprawie konsekracji władyki, uznano za zwolenników porządku. Pozostałych jednak (wśród nich główne skrzypce grali wdowa po poprzednim posadniku Marta Borecka i jej synowie) określono w tekście utworu mianem zdrajców. Przy czym jednoznacznie podkreślano, że ich zdradzieckie działania miały „nieludzki” charakter, dzięki czemu jednocześnie zwiększano dramatyzm sytuacji. „Izmen'niky” działali bowiem z poduszczenia diabła („,naučeni d'javolom”), gorzej nawet, bo ,iže goršee besove byša prelestnici na pogibel' zemli svoej i sebe na pagubu", zaczęli kusić ludność zebraną na wiecu („načjaša nelepaja i razvraščennaja glagolati”), krzycząc: „Ne chocim za velikogo knjazja moskovskogo, ni zvatisja votčinoju ego! Volnyi es'mja Velikyj Novgorod, a moskov'skij knjaz' veliky mnogi obidy i nepravdy nad namini činit”, namawiali do zwrócenia się o pomoc do króla polskiego ${ }^{44}$.

Działania podjęte z poduszczenia diabła i bardziej od niego kusicielskie dyskwalifikowały się same przez się. „Moskovskaja povest”” w tej części przekazu niczego nie stara się niuansować, nie stara się nawet próbować zrozumieć intencje, którymi kierowali się nowogrodzcy przeciwnicy hegemonii Iwana III. Wystąpienie przeciw wielkiemu księciu i przeciw całej dotychczasowej tradycji (tradycji, jak wiemy, odpowiednio podkoloryzowanej, a więc rozpatrywanej wyłącznie pod kątem moskiewskiego interesu politycznego) same w sobie były tak gorszące, że nie mogły mieć innej genezy niż szatański podszept. Tym samym, przywołane argumenty, którymi posługiwała się grupa Marty Boreckiej (nowogrodzka wolność i krzywdy doznane ze strony Moskwy), nie zasługiwały na jakąkolwiek poważną polemikę.

42 Ibidem, s. 394, 396.

${ }^{43}$ Ibidem, s. 398. Tytulatura Iwana III od lat 80. brzmiała „ruski imperator całej Rusi”, w dokumentach spisanych po niemiecku des keysers der Russzen. W 1474 r. w traktacie Nowogrodu i Pskowa z biskupem dorpackim określony został mianem „,cara”, patrz B. Uspienski, Car i imperator. Namaszczenie władcy i semantyka tytułów monarchy, tł. H. Paprocki, Katowice 2002, s. 63-64 i przyp. 27-28, s. 63, 31-32, s. 64; W. Peltz, Suwerenność państwa, s. 18. Przedstawiając wjazd Iwana III do Moskwy po odniesionym zwycięstwie, moskiewski kronikarz zapisał (PSRL, t. 12, s. 140): ,a dobiša čelom velikomu knjazju šestdesjat tysjač serebra novgorodskich rublejev, proči brati velikogo knjazja i knjazej pročich i bojar i vojevod i pročich vsech, kotoryje pečalovalisja o nich".

${ }^{44}$ Moskovskaja povest', s. 376, 378. 
Nic więc dziwnego, że opisując w dalszej części narracji militarne zmagania z Nowogrodem, autor moskiewskiej relacji sugeruje działanie cudu, dzięki któremu wojska Iwana III, ośmiokrotnie mniej liczne, zwyciężyły nad Szełonią. Nowogrodzian pokonał gniew Boga, który (autor tego wprawdzie nie werbalizuje, ale nie pozostawia najmniejszych wątpliwości, że tak sądzi) dokonał cudu. Nie dość, że rycerze moskiewscy przeszli rzekę w miejscu, gdzie miało nie być brodu, to w dodatku przeciwnicy wzięci do niewoli po bitwie opowiadali, że widzieli wojska wielkoksiążęce nie tylko o wiele liczniejsze, ale nawet znajdujące się na swoich tyłach ${ }^{45}$.

Cały Nowogród, pisał autor przekazu, ,vskolebašasja”. Jedni opowiadali się za Kazimierzem Jagiellończykiem, drudzy „po starine” za Iwanem III. To jest jedyny merytoryczny argument, choć argument nieprawdziwy, przywołany w obronie „stronnictwa ugodowego”, niebawem zresztą rozwinięty. „Stronnictwa”, które było w mniejszości, ponieważ „zdrajcy” przekupili biedotę miejską rzucającą w nich czym popadnie. Głosu „rozsądku” nie zamierzano słuchać, choć brzmiał on niezwykle wymownie: „A iznačala otčina esmy tech velikich knjazej, ot pervago velikogo knjazja našego Rjurika ..." Włodzimierz, prawnuk Ruryka, dodawano, ochrzcił się i ochrzcił całą swą ziemię, nigdy nie byliśmy łacinnikami i nigdy od nich nie dostawaliśmy arcybiskupa, jak teraz ci, którzy popierają Kazimierza Jagiellończyka, chcą „staviti ot Grigorija, nazyvajuščasja metropolitom Rusi, a učenik to Isidorov, suščej latinin" 46 .

Autor moskiewskiej relacji o wyprawie przeciw nadilmeńskiej republice włożył w usta nowogrodzkich stronników Iwana III argumentację reprezentującą wyłącznie jego punkt widzenia. „Starina” nie była objawem wolności republiki, ale podkreśleniem praw i roszczeń księcia moskiewskiego, passus poświęcony przyjęciu chrztu za czasów Włodzimierza Wielkiego stał zaś w sprzeczności z nowogrodzką tradycją o roli św. Andrzeja, apostoła. To, przyznajmy zgrabne, odwrócenie znaczenia pojęć, niejednokrotnie będzie się jeszcze, jak wiemy, w historii powtarzało.

Po takim wprowadzeniu można było bez oporów dać upust własnym emocjom. Nadeszła kolej na dalszą porcję epitetów: „Te že razvratnici, jako že i prežni eretici, naučeni d'javolom, chotjašče na svoem postaviti”, krzyczeli, że chcą króla polskiego. „Zlodejci že onii protivnici sotvorše sebe pravoslaviju, boga ne bojašesja”, wyprawili posłów (imiennie w tekście wymienionych) do Kazimierza Jagiellończyka ${ }^{47}$. Królowi „bili czołem”, wzywali go jako „gospodina" i prosili, żeby jego metropolita Grzegorz zatwierdził ich władykę, a król przysłał do nich księcia „,iz svoej deržavy”"48. Co Kazimierz uczynił,

\footnotetext{
45 Ibidem, s. 392.

${ }^{46}$ Ibidem, s. 378.

${ }^{47}$ Ibidem.

48 Ibidem, s. 380.
} 
wysyłając Michała Olelkowicza ${ }^{49}$, którego w Nowogrodzie przyjęto z czcią, chociaż nie wygnano namiestników Iwana III ,s Gorodišča”, a księcia Wasyla Garbatego ,poslaša v Zavoloč’e”. Nie pomogły „głosy rozsądku” po przyjęciu poselstwa Iwana III, o którym wspominałem, ponieważ „Isakovy deti” (synowie Marty Boreckiej) ze swymi zwolennikami ,jako vzbesnešali, jako zverii divii, bezčelovečen razum imušče, knjazja velikogo poslov rečej, takože i metropolita Filippa posla, ni slyšite ne chotjachy”. I te „dzikie zwierzęta” w dodatku wykorzystywały (tu następuje niezwykły potok pogardy) ,zlych tech smerdov, ubiic, šilnikov, i pročich bezimenitych mužikov, iže skotem podobni syt', ničto že razuma imuščich, no točiju edino kričanie, iže i bezslovesnaja i životnaja ne sice ryčachy, jako že oni novgorodstii ljudie, neveglasi, ospodarem zovjachy sebe Velikim Novym gorodom”. A „ciemnota” (ignoranci) przychodzili na wiec, bili w dzwony i krzyczeli, „lajachy, jako psi”, że chcą podporządkować się królowi. „I takovo be - podsumowywał autor opowieści - vzmuščenie v nich, jako že v Ierusalime byst', egda predast' ego gospod' $\mathrm{v}$ ruce Titove; jako že bo ti togda, tako i sii mež sebe bran'tvorjachy" ${ }^{\text {"50. Koń- }}$ cowy fragment tej konkluzji wypadał, jak widzimy, niezbyt korzystnie również dla nowogrodzkich zwolenników Iwana III. Czy w sposób zamierzony, czy jedynie przez stwierdzenie faktu wewnętrznego zamętu przeradzającego się w kłótnię - odpowiedzieć nie sposób.

Jakże skromnie w porównaniu z moskiewską relacją o wyprawie na Nowogród brzmi świadectwo zwyciężonych. „Novgorodskaja povest' o pochode Ivana III Vasil'eviča na Novgorod"51 jest króciutkim utworem pisanym przez jednego z Nowogrodzian, kładącym nacisk na militarny aspekt zmagań, który mnie $\mathrm{w}$ tej pracy $\mathrm{z}$ oczywistych względów nie interesuje. W tekście przywołano datę rozgrywających się wydarzeń i enigmatyczne stwierdzenie, że Iwan III „vverže neljubie na Velikij Novgorod”.52. Co było powodem gniewu wielkiego księcia, próżno byłoby się w tekście doszukiwać. Jest to jednocześnie najciekawszy problem, z jakim spotyka się badacz tego utworu. Dowiadujemy się natomiast z niego o postępach wojsk moskiewskich i o pomocy, jakiej Iwanowi III udzielił Psków, niszcząc wiele ziem nowogrodzkich. Bardzo ciekawa informacja (brak jej w świadectwie moskiewskim) znalazła się w początkowym fragmencie narracji. Opisując

${ }^{49}$ Patrz też PSRL, t. 3, Sankt Peterburg 1841, s. 141; t. 4, Sankt Peterburg 1848, s. 235. F. Papée, Kazimierz Jagiellończyk i jego następcy wobec Nowogrodu i Moskwy, [w:] Studia historyczne ku czci Stanisława Kutrzeby, t. 2, Kraków 1938, s. 586; idem, Polska i Litwa na przełomie wieków średnich, t. 1: Ostatnie dwunastolecie Kazimierza Jagiellończyka, Kraków 1904, s. 39-41; K. Bojko, Stosunki dyplomatyczne, s. 73. Michał Olelkowicz opuścił Nowogród w marcu 1471 r., PSRL, t. 25, Moskva-Leningrad, 1949, s. 285-288.

${ }^{50}$ Moskovskaja povest', s. 380, 382.

${ }^{51}$ Novgorodskaja povest' o pochode Ivana III Vasil'eviča na Novgorod, [w:] Pamjatniki literatury, s. 404-408.

${ }^{52}$ Ibidem, s. 404. 
starcie pieszych wojsk nowogrodzkich z oddziałami moskiewskimi w okolicach Starej Russy, autor stwierdza, że pomocy odmówiły pułki konne przysłane przez arcybiskupa, tłumacząc swą neutralność w następujący sposób: „Vladyka nam ne velel na velikogo knjazja ruki podynuti, poslal nas vladyka na p'skovič" 53 . Jest to informacja o pierwszorzędnym znaczeniu, pochodząca ze źródła doskonale poinformowanego, która rzuca jaśniejsze światło na wewnętrzne podziały polityczne w samym Nowogrodzie. Nie mniej ciekawe jest to (choć zapewne zrozumiałe z powodu sytuacji, jaka wytworzyła się w Nowogrodzie po klęsce), że autor opowieści pozostawił tę wzmiankę bez jakiegokolwiek komentarza.

„Novgorodskaja povest"” przynosi również informację o kontaktach z królem polskim, ale i tym razem w formie lakonicznej. Po wzmiance o klęsce wojsk nowogrodzkich nad Szełonią, do czego przyczyniły się oddziały tatarskie, Nowogrodzianie wyprawili posła na Litwę, ,„čtoby korol' vsel na kon' za Novgorod". Poseł próbował dojechać przez państwo zakonne, ale nie został przepuszczony na Litwę ${ }^{54}$. Dopiero wspominając o przybyciu Iwana III do Russy, autor dodał, że w Nowogrodzie przygotowującym się do walki doszło do podziału. Część mieszkańców poparła króla (,za korolja za litov'skogo"), część wielkiego księcia moskiewskiego, za co Iwan III ukarał śmiercią 4 (wymienionych w tekście imiennie) nowogrodzkich bojarów, a innych uwięził ${ }^{55}$.

Spore znaczenie mają, powściągliwe zresztą, fragmenty oddające nastroje w samym Nowogrodzie, gdzie zapanowała drożyzna i brakowało podstawowych artykułów. Największe wrażenie robi jednak fragment osądzający tych, spośród rodaków autora relacji, którzy popierali Iwana III: „I byst' na lut'šin ljudi molva, jako te privedoša velikogo knjazja na Novgorod, a to bog serdcevidec' i sudi im, začinajuščim rat' i obidjaščim nas" ${ }^{56}$. I kolejny, poświęcony zdrajcy, niejakiemu Upadyszowi, przy okazji wspominający o podobnie do niego myślących:

„A perevetnika Upadyša novgorodci kazniša, zaneže perevet deržal na Novgorod i chotel zla Velikomu Novugorodu s svoimi edinomysleniki: 5 pušok železom zakolačival, ottogo mzdy vzem ot zlonačalnago besa, i ottogo i napasti i v popolzenie pagubnoe sveta lišajuščasja, jakože Pavel reče: »Choščet i bogatitisja, vpadajut vo zlo«"57.

${ }^{53}$ Ibidem.

${ }^{54}$ Ibidem. O kontaktach Nowogrodu z zakonem inflanckim po fiasku rozmów z Kazimierzem Jagiellończykiem, patrz Liv-, Est- und Curländisches Urkundenbuch, t. 12, wyd. F.G. von Bunge, Riga-Moskva 1910, nr 840.

${ }^{55}$ Novgorodskaja povest', s. 406.

${ }^{56}$ Ibidem.

${ }^{57}$ Ibidem. 
Osąd nad zdradą jest dłuższy, pełen goryczy, a całą nadzieję, nie ukrywający przecież swych nastrojów, autor „Novgorodskiej povesti”, pokłada w Bogu:

„No ty, milostivyj Spase, prosti ruku svoju nevidimuju, izvedi nas ot vsjakogo zla i budi nam smiren pomoščnik $v$ den' pečali našija, egda vostrepeščet duša naša, vidjašči protivnyja sily. No ty, milostivyj gospodi, posli nam ot vyšnjago čestnago prestola tvoego pomošč' i oružie nepobedimoe, čestnyj krest, molitvami svjatyja bogorodica i vsech svjatych. Christos začalo spaseniju, konec' pagube"s8.

„Novgorodskaja povest'” przynosząca sporo informacji odnoszących się do militarnej strony konfliktu zakończonego klęską Nowogrodu, jest przede wszystkim wzruszającym lamentem człowieka, który nie tylko dostrzega skutki porażki, nie tylko z ogromną goryczą wypowiada się o tych, którzy nie potrafili dochować wierności swemu podstawowemu obowiązkowi, ale który, jak się wydaje, stracił wszelkie „ziemskie nadzieje”. Reszta, o czym pisał wprost, zależała już tylko od Stwórcy, którego opiece polecał swą ojczyznę.

Jak można podsumować oba świadectwa mówiące o pochodzie Iwana III na Nowogród w 1471 r., unikając powtarzania spostrzeżeń o wspomnianych wyżej celach politycznych, ideowych i propagandowych, które legły u podstaw jednego $\mathrm{z}$ tych świadectw? Można spróbować uczynić to w nieco inny sposób. Z poddanych analizie przekazów wyłaniają się następujące, najważniejsze wnioski (dla tych, rzecz jasna, konkretnych przykładów, bo generalizowanie byłoby niestosowną nadinterpretacją): zwycięzca, bez względu na okoliczności, ma zawsze rację; pokonanemu pozostaje wyłącznie opieka Boska; zwycięzca nie musi się liczyć ze słowami, za pomocą których kreśli swój tryumf; pokonanemu pozostają wyłącznie smutek i gorycz, które może przekazać potomnym; zwycięzca nie musi szanować pokonanych; zwyciężony, choć wcale niepokonany, nie musi jednak kłaniać się zwycięzcom; i zwycięzca, i pokonany mogą dawać świadectwo przyszłym pokoleniom, próbując je czegoś nauczyć.

${ }^{58}$ Ibidem, s. 408. 